\title{
IDENTIFYING AND MEASURING THE WEIGHTS OF HALAL COMPLIANCE RATING (HCR) COMPONENTS OF BEST HALAL PRACTICES BY APPLYING AHP METHOD
}

\author{
Md Siddique E Azam ${ }^{1 *}$, Moha Asri Abdullah², Anis Nijiha Ahmad ${ }^{3}$ \\ *Corresponding Author \\ ${ }^{1}$ International Institute for Halal Research and Training, International Islamic University Malaysia, Malaysia, \\ siddique77hstu@gmail.com \\ ${ }^{2}$ International Institute for Halal Research and Training, International Islamic University Malaysia, Malaysia, \\ mosri@iium.edu.my \\ ${ }^{3}$ International Institute for Halal Research and Training, International Islamic University Malaysia, Malaysia, \\ anisnajiha@iium.edu.my
}

\begin{abstract}
The halal industry in the restaurant chain is lacking a rating system that would help the consumers to choose their preferences and enhance halal integrity. In this regard, as a first step to develop a halal compliance rating (HCR) tool, the first objective of this research is to identify and select the components of best halal practices for restaurants. The second objective is investigating the auditable and measurable areas of the selected ten HCR components. The objectives were achieved by reviewing existing relevant rating systems, standards, and research papers. The selected ten components were weighed by applying the Analytic Hierarchy Process (AHP) method of decision making through the participation of 15 experts where the maximum priority was given to the 'Hygiene and Food Safety (HFS)' component with a weightage of $22.3 \%$. The least priority was given to 'Branding, Packaging, and Labelling (BPL)' with a weightage of $4.4 \%$. The consistency ratio was checked as 0.015 . Additionally, the study investigates the auditable and measurable areas of the selected ten HCR components.
\end{abstract}

Keywords: rating, halal compliance, AHP, halal restaurants.

Received

June 7, 2021

To cite this article:
Revised

September 9, 2021
Accepted

September 14, 2021
Published

September 30, 2021

Azam, M. S. E., et al. (2021). Identifying and measuring the weights of halal compliance rating (HCR) components of best halal practices by applying AHP method. IJIBE (International Journal of Islamic Business Ethics), 6 (2), 104-118. http://dx.doi.org/10.30659/ijibe.6.2.104-118

\section{INTRODUCTION}

It is important for any business, whether it is product or service-based, to comply with the standards, and qualities for the respective management, and operational practices. One such market in the global economy is the global halal industry. With a global market value of US\$2.3 trillion (excluding Islamic finance) the Halal industry, now, is one of the fastestgrowing markets in the world (Elasrag, 2016). As the concept 'halal' (permissible) also associates the concept 'Toyyib' (good quality), the consumer size of the market is increasing at an annual rate of 20 percent with the growing Muslim population globally (Pacific, 2010). Apart from Islamic finance that occupies a 43 percent share of the market, the Halal food industry positions second occupying a 36 percent share of the market (Global Halal Market Statistics \&amp; Facts | Statista, n.d.). As the leading country in the Islamic economy, Malaysia has its' significant role to establish a strong and comprehensive halal standard 
(Thomson Reuters and DinarStandard, 2018). One of the standards is the Malaysian Standard (MS)- 1500 is for Halal foods and beverages.

According to the 2015 economic census which was released in 2017, a total of 6,138 establishments received Halal certificates and the number of applications is increasing tremendously every year (Department of Statistics Malaysia, 2017). Like any other certification system for any standard, the Halal certification system also has its monitoring and auditing bodies to ensure the compliance of certified business organizations towards halal standards and requirements. In this regard, researches have been conducted on halal compliance by a limited number of researchers that include Ly et al. (2015); Randeree (2019); Mohamed, Mahmood, \& Mansor (2014); Salindal, (2018); Baharuddin \& Ismail, (2018); Mohamed et al., (2014); Sorooshian \& Dahan, (2013); Rahman, Saleh, Rahman, \& Hashim (2012); Zailani, Omar, \& Kopong (2011), and others. One of the common problem statements of all these studies was the issue of monitoring halal compliance in the business, related requirements and laws, and constraints.

The existing measuring practice by JAKIM is on the non-compliance level of halalcertified businesses. These levels are rated as 'minor offence', 'major offence', and 'serious offence' (JAKIM, 2015). However, these measurements are merely based on violating any standard or lacking any requirements (MS-1500:2019). The most relevant halal compliance measurement is the consumer purchasing decision based on the hotel rating system while choosing any hotel for their stay. This is known as Muslim-Friendly Hospitality Services (MFHS) known as MS2610:2015. Having such a compliance level enables any business to make a competitive position in the market (Asia Pulp \& Paper, 2019; Veit, Lambrechts, Quintens, \& Semeijn, 2018).

The global halal food and beverage market spending in 2017 was US\$1.3 trillion which is projected to reach US\$1.9 trillion by 2023 (Thomson Reuters and DinarStandard, 2018). This statistical evidence implies the increasingly high demand for halal foods and beverages (F\&B) globally. One of the biggest service providers in this sector is the restaurants scattered in different locations in the market. Simultaneously, the responsibility of providing the faithbased needs (halal and Toyyib foods) of consumers is shouldered on the halal-certified restaurant operators (Rahman et al., 2012). In the context of Malaysia, the duties or obligations for halal-certified restaurant providers are reflected by the Halal Standard 1500:2019. However, some recent non-compliance issues in halal restaurants have raised concerns among consumers regarding the reliability of halal certification in Malaysia (Tiema, 2019; Rahman et al., 2012).

In this regard, the researcher was not aware of any existing research or study that was carried out to measure the halal compliance level and rate them accordingly. Additionally, an attempt to identify and select the components of best halal compliance practice has been lacking in the research fields. Such research gap regarding the halal certification and halal compliance is also needed to be filled in to strengthen the confidence level of consumers choosing halal products and services as it has become one of the significant challenges in the Halal industry, especially in the halal food sector (Randeree, 2019). This is also needed to reflect the effectiveness of the halal practices by a business to ensure compliance with Halal standards and requirements, and to reduce the tendency of harming consumers which can be caused by providing poor or non-compliant products and services. Such issues on halal non- 
compliance have been addressed by a number of scholars (Journal \& Basic, 2016; Tiema, 2019; Tieman, 2017; Yapp \& Fairman, 2005; Rezai et al., 2012) where consumer trust in halal logo has been identified to be shaken because of poor monitoring and ineffective implementation of the halal standard by JAKIM personnel.

To address the issues stated above, the present study sets the following to objectives-

1. To identify and measure the weights of the components of best halal compliance practice by the halal-certified restaurants in Malaysia.

2. To identify the auditable and measurable areas of HCR components.

The study is significant as it will minimize the research gap by providing the components of best halal compliance practices for halal-certified restaurants that are lacking by the halal industry. The selected components can be used as the areas of investigation to measure the best halal compliance practice of a halal-certified restaurant. Additionally, the achievement of the objectives of the present study will be the successful completion of the initial step of developing an HCR tool in the future. Moreover, measuring the weights of the selected components will assist to decide on which components should be prioritized while preparing an audit checklist in measuring halal compliance. Finally, it will be a great contribution to the calculation of HCR in the future study of implementing and validating the HCR tool.

\section{LITERATURE REVIEW}

To select the components of best halal compliance practices, the existing standards, and rating systems, that are relevant to the halal restaurant industry, have been reviewed. Additionally, relevant research papers by previous scholars have also been reviewed to identify and select the list of the components of best halal compliance practices.

\section{Malaysian Standard, MS 1500:2019}

In the context of Malaysia, halal compliance has been defined by the Malaysian Standard, MS 1500:2019, Halal Food Production, Preparation, Handling, and Storage- General Guidelines (Third revision). The guidelines explain compliance as the fulfilment of the requirements as mentioned in clause 3 of the standard which shall be verified through site inspection. The MS 1500: 2019 for Halal Food considers eight different aspects relevant to halal foods to provide the requirements to ensure halal compliance by any business that uses or intends to use the halal logo. The eight different aspects are as follows-

i. Management responsibility

ii. $\quad$ Premises and equipment

iii. Devices, utensils, machines, and processing aids

iv. Hygiene, sanitation, and food safety

v. Processing of halal food

vi. Storage, transportation, display, sale, and serving of halal food

vii. Packaging and labelling

viii. Legal requirements

\section{Malaysian Standard MS2610:2015}


Malaysia has also developed the standard for Muslim-Friendly Hospitality Services (MFHS) known as MS2610:2015. According to the standard, both general and specific requirements for MFHS certification are distributed into five main components that include management responsibilities, accommodation, tour packages, and tour guide requirements.

\section{ISO 22000 Food Safety Management System (FSMS)}

ISO 22000 is a globally accepted standard that addresses aspects of food safety issues. It outlines the obligation for any organization or company in the food chain that is relevant to the food supply chain to show its ability to monitor food safety risks in order to guarantee that food is healthy at the time of human consumption. The standard sets its compliance requirements under seven core elements that include organizational context, leadership, planning, support, operation, performance evaluation, and improvement (ISO, 2018).

\section{Food Hygiene Regulation 2009}

Additionally, the halal certification for restaurant and food premises becomes smoother and flexible when the restaurant or food premise has a grading (A, B, C, or D) under the Food Hygiene Regulation 2009. This regulation by the Food Safety and Quality Division under the Ministry of Health Malaysia (Food Safety and Quality Division \& Malaysia, 2009) provides the requirements to be fulfilled by the restaurant operators under eight major components that focus on food safety, traceability, management, premise, and storage packaging and labelling.

\section{Crescent Muslim Friendly Hotel Rating}

The most popular Muslim friendly hotel rating system is the Crescent Muslim Friendly Hotel Rating system. It investigates different aspects of halal under four major components to rate the halal compliance of any hotel that include facilities regarding halal food, prayer, and Ramadan service (Crescent Rating, n.d.).

\section{Clean, Safe, and Healthy (BeSS) certification Malaysia}

Another voluntary scheme in the foodservice industry is the BeSS certification under the ministry of health $(\mathrm{MoH})$. This recognition is to motivate food service providers to serve clean, safe, and healthy food to consumers. About 6,000 food premises have been awarded with BeSS certification since 2013 which includes school and university canteen, cafeteria, kiosk, and food trucks (Grace Chen, 2019). The certification requirements are set under two main components which are, (A) safety and quality, and (B) Nutritional aspects. These two components further consider clean and safe food, clean premises, and other management aspects.

\section{Review of Existing Research Works}

While MS1500:2009 states the components of halal compliance and explains the requirements under each component, studies by previous research scholars consider some additional components to investigate or examine the halal compliance and halal certification system in Malaysia. The standard provides the minimum requirements for the business companies in the F\&B sector to get the halal certification and the license to use the halal logo on the labelling of their products and services. To measure halal compliance and rate them 
accordingly, it is essential to identify and recommend the best practice in halal compliance. Many scholars studied and conducted research on factors that influence effective quality and food safety management. In this regard, Table 1 identifies the halal compliance components reviewing previous relevant studies.

Table 1: Identifying components of halal compliance from previous relevant studies

\begin{tabular}{|c|c|c|}
\hline Source & Topic & Components of Halal Compliance \\
\hline Ahmad (2018) & $\begin{array}{l}\text { Implementation of Halal Food } \\
\text { Management System in Small and } \\
\text { Medium Enterprises Food } \\
\text { Manufacturers }\end{array}$ & $\begin{aligned} \text { i. } & \text { Resources/ Company attributes } \\
\text { ii. } & \text { Top management/ leadership } \\
\text { iii. } & \text { Employee/people } \\
\text { iv. } & \text { Education and training } \\
\text { v. } & \text { Process } \\
\text { vi. } & \text { Suppliers, and } \\
\text { vii. } & \text { External factors like consumers, regulations, } \\
& \text { and government. }\end{aligned}$ \\
\hline $\begin{array}{ll}\text { Baharuddin } & \& \\
\text { Ismail (2018) } & \end{array}$ & $\begin{array}{l}\text { Halal compliance impact on } \\
\text { organizational performance: The } \\
\text { role of religiosity }\end{array}$ & $\begin{array}{cl}\text { i. } & \text { Halal and Toyyib practices } \\
\text { ii. } & \text { Internal process } \\
\text { iii. } & \text { Halal assurance system, and } \\
\text { iv. } & \text { Human resource capability. }\end{array}$ \\
\hline $\begin{array}{l}\text { Zannierah Syed } \\
\text { Marzuki, Hall, \& } \\
\text { Ballantine (2012) }\end{array}$ & $\begin{array}{l}\text { Restaurant managers' perspectives } \\
\text { on halal certification }\end{array}$ & $\begin{aligned} & \text { i. } \text { Knowledge on halal, Muslim dietary law, } \\
& \text { and practice of religion in the workplace } \\
& \text { ii. } \\
& \text { iii. } \\
& \text { Hampliance with food hygiene regulations } \\
& \text { iv. } \\
& \text { v. Hyppliers } \\
& \text { Hygiene and safety of the premise } \\
& \text { Islamic environment }\end{aligned}$ \\
\hline $\begin{array}{ll}\text { Zannierah } & \& \\
\text { Marzuki (2016) } & \end{array}$ & $\begin{array}{l}\text { Halal Certification: A Viewpoint } \\
\text { from Malaysian } \\
\text { Managers }\end{array}$ & $\begin{array}{cl}\text { i. } & \text { Cleanliness in food production, kitchen, } \\
& \text { restroom, and dining area } \\
\text { ii. } & \text { Good Hygiene Practice (GHP), and food } \\
& \text { safety } \\
\text { iii. } & \text { Muslim dietary laws } \\
\text { iv. } & \text { Islamic atmosphere }\end{array}$ \\
\hline $\begin{array}{l}\text { Razalli, Abdullah, } \\
\& \text { Yusoff (2013) }\end{array}$ & $\begin{array}{l}\text { The Influence of Human factors in } \\
\text { Halal Certification Process on } \\
\text { Organizational Performance }\end{array}$ & $\begin{aligned} \text { i. } & \text { Management responsibility } \\
\text { ii. } & \text { Staff policy } \\
\text { iii. } & \text { Staff characteristics }\end{aligned}$ \\
\hline $\begin{array}{l}\text { Rahman et al. } \\
\text { (2012); Sorooshian } \\
\text { \& Dahan }(2013)\end{array}$ & $\begin{array}{l}\text { A Review on factors of non- } \\
\text { compliance of halal standards } \\
\text { among restaurant operators in } \\
\text { Kuala Lumpur }\end{array}$ & $\begin{aligned} \text { i. } & \text { Knowledge on halal } \\
\text { ii. } & \text { Implementation cost } \\
\text { iii. } & \text { Management responsibility } \\
\text { iv. } & \text { Supplier issues } \\
\text { v. } & \text { Customer satisfaction } \\
\text { vi. } & \text { Halal governance, and } \\
\text { vii. } & \text { Monitoring and enforcement }\end{aligned}$ \\
\hline Salindal (2019) & 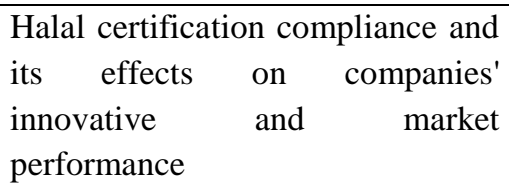 & $\begin{array}{cl}\text { i. } & \text { Raw material } \\
\text { ii. } & \text { Processing } \\
\text { iii. } & \text { Product innovation } \\
\text { iv. } & \text { Marketing }\end{array}$ \\
\hline $\begin{array}{l}\text { Baharuddin } \quad \& \\
\text { Ismail (2018) }\end{array}$ & $\begin{array}{l}\text { Halal compliance impact on } \\
\text { organizational performance: The } \\
\text { role of religiosity }\end{array}$ & $\begin{array}{l}\text { The practice of halan Toyyiban } \\
\text { Internal process of business organization } \\
\text { Halal assurance management system } \\
\text { Capacity and capability of human resources }\end{array}$ \\
\hline Tan, Lau, Yong, & A qualitative study of green & Water and energy \\
\hline
\end{tabular}




\begin{tabular}{|l|l|rl|}
\hline Khan, \& Nguyen & practices adoption for restaurants & & conservation \\
$(2019)$ & in Malaysia & ii. & The practice of recycling and compositing \\
& & iii. & Use of sustainable, local, and organic foods \\
& & iv. & No toxic and chemical products \\
& & v. & $\begin{array}{l}\text { Sustainable furnishing and building } \\
\text { materials (for new buildings) }\end{array}$ \\
\hline
\end{tabular}

\section{METHODS}

The study was strategized into two major stages and the methodology was adopted accordingly. Firstly, to achieve the first objective, an extensive review of secondary data was conducted from three different categories of resources. These resources included existing relevant standards and regulations, rating systems, and previous research works in relevant fields of the halal food industry.

The second stage was to prioritize and measure the weights of the identified components of best halal compliance practices by halal-certified restaurants in Malaysia. In this regard, the Analytic Hierarchy Process (AHP) method of decision making was adopted involving 15 experts from the halal food and beverage industry and other relevant sectors. The present study adopted the AHP tool (Microsoft Excel format) developed by Goepel, (2013).

\section{Prioritizing the Selected Components of Best Halal Compliance Practice}

The significance of all the components for measuring halal compliance is not equal. One is more or less important than another. Therefore, the weightage of each component will also vary. To distribute the weightage over all the selected components fairly and with justification, the most widely used tool is the Analytic Hierarchy Process (AHP). The following section provides an explanation and use of this tool reviewing previous literature.

\section{Analytic Hierarchy Process (AHP)}

Analytic Hierarchy Process in short AHP is a theory developed and introduced by Thomas Saaty (1980). It is considered to be one of the most effective tools in the Multiple Criteria Decision Making (MCDM) process (Soberi \& Ahmad, 2016).

AHP tool includes creating pairwise comparisons between the selected components to identify priority weights halal compliance along with evaluating the relative ranking of various HCR components considered in the study. The second level of the process involves prioritizing the criteria or different components by assigning a certain percentage of weights by multiple expertise in relevant fields (Singh et al., 2020). The reason for involving multiple expertise in the weighing phase is to ensure consistency in the weightage of each component (Vaidya \& Kumar, 2006).

The tool was sent to the experts along with a request letter to contribute to this research. The tool included the definition of all the ten selected HCR components as shown in Table 3.1. Additionally, there were a total of 45 different pairs from the $10 \mathrm{HCR}$ components. Experts were requested to prioritize the components between each pair and put a score based on the Saaty scale (Table 2) of importance which was also provided in the AHP tool. 
Table 2: Saaty Scale of the relative importance

\begin{tabular}{|l|l|}
\hline Measuring Scale & Score \\
\hline Equal importance & 1 \\
\hline Moderate importance & 3 \\
\hline Strong importance & 5 \\
\hline Very strong importance & 7 \\
\hline Extreme importance & 9 \\
\hline \multirow{4}{*}{ Intermediate values } & 2 \\
\cline { 2 - 2 } & 4 \\
\cline { 2 - 2 } & 6 \\
\cline { 2 - 2 } & 8 \\
\hline
\end{tabular}

\section{RESULT}

\section{Identified Components of HCR and Auditable Areas}

The literature review section presents the halal compliance components by reviewing different standards, regulations, and rating systems that exist and are relevant to the halal industry. Additionally, it investigates the halal compliance components from a number of previous studies conducted by different research scholars. From this extensive investigation, ten components have been identified to be considered for HCR of best halal practice by the food premises. The components were selected based on their most frequent appearance in different standards, regulations, rating systems, and previous research works. Table 3 presents the auditable items against each of the ten selected components of HCR for halalcertified food premises and restaurants.

Table 3: Auditable and measurable items of selected HCR components

\begin{tabular}{|c|c|c|c|}
\hline No. & $\begin{array}{l}\text { Selected } \mathrm{HCR} \\
\text { components }\end{array}$ & Auditable and measurable items & Reference \\
\hline \multirow[t]{3}{*}{1.} & \multirow[t]{3}{*}{$\begin{array}{l}\text { Knowledge of } \\
\text { halal and Toyyib } \\
(\mathrm{KNW})\end{array}$} & $\begin{array}{l}\text { knowledge on the meaning and implication } \\
\text { of the word Halal } \\
\text { knowledge on the meaning and implication } \\
\text { of the term Toyyib }\end{array}$ & STANDARD, (2019) \\
\hline & & $\begin{array}{l}\text { Knowledge of Toyyib to realize the critical } \\
\text { points (e.g., transportation, receiving and } \\
\text { storing inventory, processing foods, raw } \\
\text { materials and ingredients, and serving) in the } \\
\text { supply chain (farm to fork). }\end{array}$ & $\begin{array}{l}\text { Baharuddin \& Ismail, } \\
\text { (2018) }\end{array}$ \\
\hline & & $\begin{array}{l}\text { Halal and Toyyib knowledge to maintain } \\
\text { good gestures (e.g., behaviour, appearance, } \\
\text { Islamic greetings, etc.), presentation } \\
\text { (presenting foods, presenting yourself, and } \\
\text { overall presentation of the restaurant), and } \\
\text { service. }\end{array}$ & $\begin{array}{cc}\text { Zannierah } & \text { Syed } \\
\text { Marzuki et al., (2012) } & \end{array}$ \\
\hline \multirow[t]{2}{*}{2.} & \multirow[t]{2}{*}{$\begin{array}{c}\text { Management } \\
\text { responsibility }(\mathrm{MGT})\end{array}$} & $\begin{array}{l}\text { Establishment of Internal Halal Committee } \\
\text { (IHC), Internal Halal control system, } \\
\text { appointing Muslim personnel, providing } \\
\text { training on halal awareness and knowledge, } \\
\text { arranging a regular meeting }\end{array}$ & $\begin{array}{l}\text { STANDARD, (2019); } \\
\text { MS 2610, (2015) }\end{array}$ \\
\hline & & $\begin{array}{l}\text { Sufficient resources (manpower, facility, } \\
\text { finances, and infrastructure) to implement the }\end{array}$ & ISO, (2018) \\
\hline
\end{tabular}




\begin{tabular}{|c|c|c|c|}
\hline & & internal halal control system & \\
\hline & & $\begin{array}{l}\text { Staff participation in the decision-making } \\
\text { process }\end{array}$ & AHMAD, (2018) \\
\hline & & Allowing staff to perform their prayers & $\begin{array}{l}\text { Rahman et al., (2012); } \\
\text { Razalli et al., (2013) }\end{array}$ \\
\hline \multirow[t]{5}{*}{3.} & \multirow[t]{5}{*}{$\begin{array}{l}\text { Premise location } \\
\text { and design (PLD) }\end{array}$} & $\begin{array}{l}\text { Dedicated and segregated space for prayer, } \\
\text { proper service flow, no entry of pets and } \\
\text { animals }\end{array}$ & STANDARD, (2019) \\
\hline & & Muslim friendly sanitary facilities & MS 2610, (2015) \\
\hline & & $\begin{array}{l}\text { Segregated from pig farm (min } 5 \mathrm{~km} \\
\text { away), and ensures no entry of pig-products or } \\
\text { any descendants from pig }\end{array}$ & STANDARD, (2019b) \\
\hline & & Proper employee flow & Ahmad, (2018) \\
\hline & & $\begin{array}{l}\text { Premise design that ensures proper } \\
\text { cleaning process }\end{array}$ & $\begin{array}{c}\text { Romeiss-Stracke, } \\
\text { (1995); Salindal, (2019) }\end{array}$ \\
\hline \multirow[t]{6}{*}{4.} & \multirow{6}{*}{$\begin{array}{l}\text { Hygiene and food } \\
\text { safety (HFS) }\end{array}$} & Good Hygiene Practice (GHP) grading & \multirow{3}{*}{$\begin{array}{l}\text { STANDARD, (2019); } \\
\text { MS 2610, (2015) }\end{array}$} \\
\hline & & $\begin{array}{l}\text { Regular cleaning of all devices and kitchen } \\
\text { utensils, washbasins, sits, garbage cans, and } \\
\text { toilets }\end{array}$ & \\
\hline & & $\begin{array}{l}\text { Proper ventilation and adequate lighting to } \\
\text { ensure safe storage of foods and pleasant } \\
\text { atmosphere at kitchen and storage area }\end{array}$ & \\
\hline & & $\begin{array}{l}\text { Frequent cleaning and changing of } \\
\text { tabletops, and chairs }\end{array}$ & $\begin{array}{r}\text { Food Safety and Quality } \\
\text { Division \& Malaysia, (2009) }\end{array}$ \\
\hline & & No dripping and clogging in water pipes & Marzuki et al., (2012); \\
\hline & & $\begin{array}{l}\text { Pest control measure to eliminate any } \\
\text { presence of cockroaches, ants, flies, rats, etc. }\end{array}$ & $\begin{array}{l}\text { Ungku Fatimah et al., } \\
\text { (2011); Zannierah } \quad \text { \& } \\
\text { Marzuki, (2016) }\end{array}$ \\
\hline \multirow[t]{3}{*}{5.} & \multirow[t]{3}{*}{$\begin{array}{l}\text { Human resource } \\
\text { and culture (HRC) }\end{array}$} & $\begin{array}{l}\text { Capacity building of staffs by providing } \\
\text { training }\end{array}$ & Ahmad, (2018) \\
\hline & & 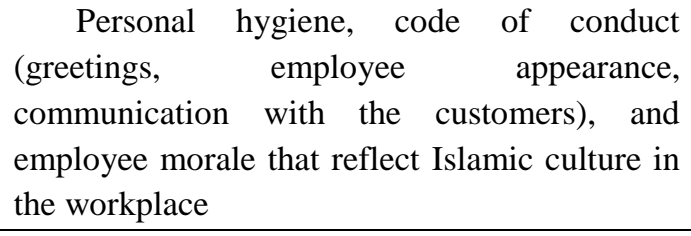 & $\begin{array}{l}\text { Baharuddin \& Ismail, } \\
\text { (2018) }\end{array}$ \\
\hline & & $\begin{array}{l}\text { Specifically designed attire for working } \\
\text { staffs, and Islamic atmosphere }\end{array}$ & $\begin{array}{l}\text { STANDARD, } \\
\begin{array}{l}(2019) ; \\
\text { Zannierah \& } \\
(2016)\end{array}\end{array}$ \\
\hline \multirow[t]{2}{*}{6.} & \multirow[t]{2}{*}{$\begin{array}{l}\text { Branding, } \\
\text { packaging, } \\
\text { labelling (BPL) }\end{array}$} & $\begin{array}{l}\text { The packaging design, sign, symbols, logo, } \\
\text { name, pictures are compliant with shari'ah. } \\
\text { All marketing activities (e.g., leaflets, } \\
\text { social media advertising, etc.) comply with } \\
\text { Shari'ah principles. } \\
\text { All packaging materials are non-hazardous } \\
\text { and halal compliant. }\end{array}$ & $\begin{array}{l}\quad \text { Department } r \text { of } \\
\text { Standards Malaysia, (2014); } \\
\text { STANDARD, (2019); } \\
\text { Noordin et al., (2009) }\end{array}$ \\
\hline & & $\begin{array}{l}\text { Labelling and information on our food } \\
\text { menus and products fulfil the requirements of } \\
\text { halal certification. }\end{array}$ & JAKIM, (2015) \\
\hline 7. & $\begin{array}{l}\text { Company image } \\
\text { and level of customer } \\
\text { satisfaction (ICS) }\end{array}$ & $\begin{array}{l}\text { Overall image (reputation) of the } \\
\text { restaurant or food premise locally } \\
\text { Survey on service quality, and customer } \\
\text { satisfaction }\end{array}$ & $\begin{array}{l}\text { Sorooshian \& Dahan, } \\
\text { (2013); Ungku Fatimah et } \\
\text { al., (2011) }\end{array}$ \\
\hline
\end{tabular}




\begin{tabular}{|c|c|c|c|}
\hline 8. & $\begin{array}{c}\text { Legal } \\
\text { Requirement (LR) }\end{array}$ & $\begin{array}{l}\text { The staffs and food handlers have training } \\
\text { on food handling and a certificate of anti- } \\
\text { typhoid vaccination. } \\
\text { Halal certification is up to date and the } \\
\text { halal mark is displayed in front of the } \\
\text { restaurant. } \\
\text { Halal files and relevant documents are } \\
\text { prepared and maintained properly. } \\
\text { No misuse of the halal logo (e.g., stamping } \\
\text { the halal logo on a food product that has not got } \\
\text { a halal certificate). }\end{array}$ & $\begin{array}{l}\text { STANDARD, (2019); } \\
\text { JAKIM, (2015); Food Safety } \\
\text { and Quality Division \& } \\
\text { Malaysia, (2009) }\end{array}$ \\
\hline \multirow[t]{2}{*}{9.} & \multirow[t]{2}{*}{\begin{tabular}{lr}
\multicolumn{2}{r}{ Green practice } \\
and & sustainability \\
(GPS) &
\end{tabular}} & $\begin{array}{l}\text { Use of disposable items. e.g., toilet paper, } \\
\text { kitchen mats, glass bottles, cardboards, wood } \\
\text { boxes, cups, etc. }\end{array}$ & ISO, (2018) \\
\hline & & $\begin{array}{l}\text { Well managed use of water. } \\
\text { Minimized food waste. } \\
\text { Minimized use of plastic. } \\
\text { The practice of the principles of 3Rs } \\
\text { (reduce, reuse, and recycle). }\end{array}$ & $\begin{array}{l}\text { Romeiss-Stracke, } \\
\text { (1995); Tan et al., (2019); } \\
\text { Ungku Fatimah et al., (2011) }\end{array}$ \\
\hline \multirow[t]{2}{*}{10.} & \multirow[t]{2}{*}{$\begin{array}{cc}\text { Halal } & \text { supply } \\
\text { chain (HSC) }\end{array}$} & $\begin{array}{l}\text { Suppliers are halal certified. } \\
\text { Dedicated vehicles to carry only halal food } \\
\text { items. } \\
\text { Maintain the detailed record of loading and } \\
\text { unloading }\end{array}$ & \begin{tabular}{lr}
\multicolumn{1}{c}{ STANDARD, } & $(2019) ;$ \\
JAKIM, & $(2015) ;$ \\
(Baharuddin \& Ismail, 2018)
\end{tabular} \\
\hline & & $\begin{array}{l}\text { Halal integrity in the supply chain, i.e., } \\
\text { maintain the freshness, quality, etc. }\end{array}$ & $\begin{array}{l}\text { Yahya et al., (2016); } \\
\text { Marzuki et al., (2012) }\end{array}$ \\
\hline
\end{tabular}

\section{Experts' Opinion on the Selection of the HCR Components}

Firstly, the experts were asked to put their opinion regarding what level they agree or disagree that the selected HCR components are important and relevant for the Halal Compliance Rating (HCR) of restaurants in Malaysia. For this survey, a five-point Likert scale was used where 5 denoted 'strongly agree; and score 1 denoted 'strongly disagree'. Figure 1 shows the overall opinion of the 20 experts. The radar chart (Figure 1) shows that all 20 experts are in the layer of 'strongly agree (5)' or 'agree (4)' which justifies that the selected HCR components are important and relevant for the halal compliance rating of restaurants in Malaysia. 
Figure 1: Experts' opinion on the selected 10 components of HCR

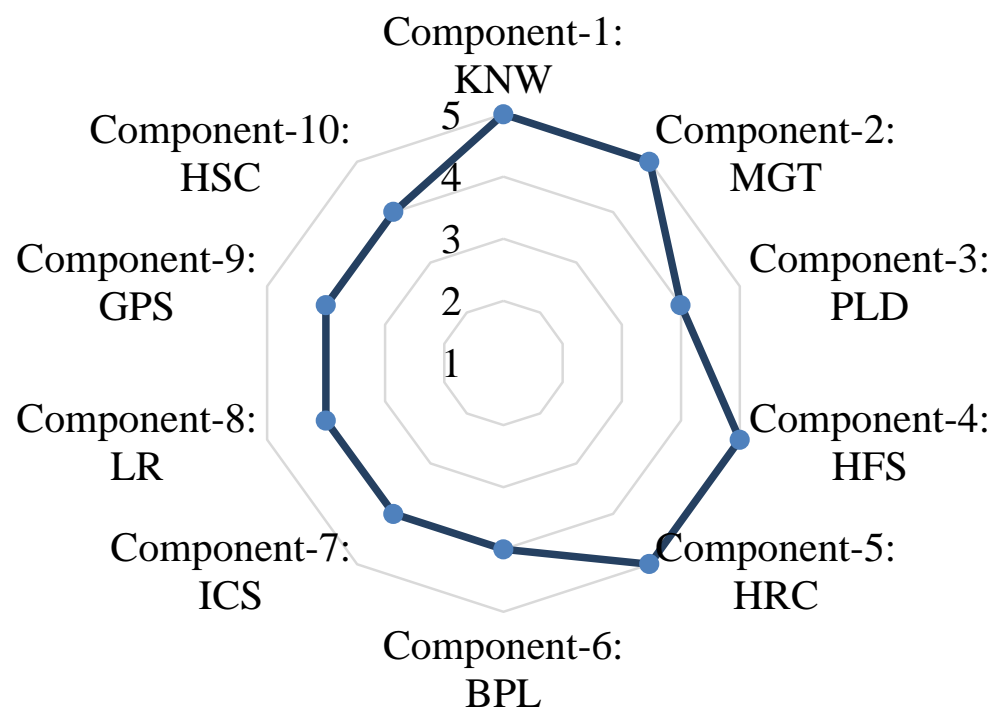

Source: Research survey

\section{Weights of Selected HCR Components}

\section{Pairwise comparison matrix}

Out of twenty experts, fifteen (15) had responded and sent back their feedback on the pairwise comparison. A total of 45 unique pairs were found among the ten components using the mathematical formula $\{\mathrm{n}(\mathrm{n}-1)\} / 2$ (Zwillinger, 2018). Table-4 shows the pairs in a matrix format. Each expert put their priority score against each pair following the Saaty scale (Table 2 ) on the provided AHP excel tool. The AHP tool uses the weighted geometric mean of the decision matrices components to combine all 15 participants' inputs and get an aggregated group matrix as shown in Table 4. The table forms the matrix showing the value of importance for each HCR component over another. For example, PLD has importance of less than 1 (below equal importance) over both KNW and MGT in row 3. In another way, both KNW and MGT gets an intermediate score between 1 and 3 implying importance between equal to moderate over PLD. The diagonal value (1) shows equal importance.

Table 4: AHP Pairwise comparison matrix

\begin{tabular}{|l|l|l|l|l|l|l|l|l|l|l|}
\hline & KNW & MGT & PLD & HFS & HRC & BPL & ICS & LR & GPS & HSC \\
\hline KNW & 1.00 & 1.00 & 2.25 & 0.78 & 3.00 & 2.88 & 3.22 & 1.33 & 3.33 & 1.75 \\
\hline MGT & 1.00 & 1.00 & 2.00 & 0.71 & 3.17 & 3.00 & 3.14 & 1.00 & 4.50 & 2.25 \\
\hline PLD & 0.44 & 0.50 & 1.00 & 0.33 & 1.71 & 2.00 & 2.13 & 1.00 & 1.14 & 0.71 \\
\hline HFS & 1.28 & 1.41 & 3.03 & 1.00 & 5.20 & 4.50 & 4.40 & 2.38 & 5.00 & 2.60 \\
\hline HRC & 0.33 & 0.32 & 0.58 & 0.19 & 1.00 & 0.75 & 0.60 & 0.33 & 1.00 & 0.43 \\
\hline BPL & 0.35 & 0.33 & 0.50 & 0.22 & 1.33 & 1.00 & 0.78 & 0.40 & 0.67 & 0.33 \\
\hline ICS & 0.31 & 0.32 & 0.47 & 0.23 & 1.67 & 1.28 & 1.00 & 1.00 & 0.78 & 0.50 \\
\hline LR & 0.75 & 1.00 & 1.00 & 0.42 & 3.03 & 2.50 & 1.00 & 1.00 & 1.67 & 1.00 \\
\hline GPS & 0.30 & 0.22 & 0.88 & 0.20 & 1.00 & 1.49 & 1.28 & 0.60 & 1.00 & 0.67 \\
\hline HSC & 0.57 & 0.44 & 1.41 & 0.38 & 2.33 & 3.03 & 2.00 & 1.00 & 1.49 & 1.00 \\
\hline Total & 6.34 & 6.54 & 13.12 & 4.47 & 23.44 & 22.43 & 19.55 & 10.04 & 20.58 & 11.24 \\
\hline
\end{tabular}

Source: Research survey 
2. Normalized pair-wise matrix

After putting the value of importance, the matrix was normalized by dividing each value by its' column total. For example, the value 0.16 in the first cell of Table 5 was obtained by dividing the value 1 by its column total 6.34 from Table 4 . After that, the weights of the components were calculated by averaging each of the rows as shown in Table 5. For example, the average of the row total for the component ' $\mathrm{KNW}$ ' is 1.53 or in percentage 15.3.

Table 5: Normalized pair-wise matrix and components' weights

\begin{tabular}{|l|l|l|l|l|l|l|l|l|l|l|l|}
\hline & KNW & MGT & PLD & HFS & HRC & BPL & ICS & LR & GPS & HSC & Weight \\
\hline KNW & 0.16 & 0.15 & 0.17 & 0.17 & 0.13 & 0.13 & 0.16 & 0.13 & 0.16 & 0.16 & $15.3 \%$ \\
\hline MGT & 0.16 & 0.15 & 0.15 & 0.16 & 0.14 & 0.13 & 0.16 & 0.10 & 0.22 & 0.20 & $15.7 \%$ \\
\hline PLD & 0.07 & 0.08 & 0.08 & 0.07 & 0.07 & 0.09 & 0.11 & 0.10 & 0.06 & 0.06 & $7.9 \%$ \\
\hline HFS & 0.20 & 0.22 & 0.23 & 0.22 & 0.22 & 0.20 & 0.23 & 0.24 & 0.24 & 0.23 & $22.3 \%$ \\
\hline HRC & 0.05 & 0.05 & 0.04 & 0.04 & 0.04 & 0.03 & 0.03 & 0.03 & 0.05 & 0.04 & $4.1 \%$ \\
\hline BPL & 0.05 & 0.05 & 0.04 & 0.05 & 0.06 & 0.04 & 0.04 & 0.04 & 0.03 & 0.03 & $4.4 \%$ \\
\hline ICS & 0.05 & 0.05 & 0.04 & 0.05 & 0.07 & 0.06 & 0.05 & 0.10 & 0.04 & 0.04 & $5.5 \%$ \\
\hline LR & 0.12 & 0.15 & 0.08 & 0.09 & 0.13 & 0.11 & 0.05 & 0.10 & 0.08 & 0.09 & $10.0 \%$ \\
\hline GPS & 0.05 & 0.03 & 0.07 & 0.04 & 0.04 & 0.07 & 0.07 & 0.06 & 0.05 & 0.06 & $5.4 \%$ \\
\hline HSC & 0.09 & 0.07 & 0.11 & 0.09 & 0.10 & 0.14 & 0.10 & 0.10 & 0.07 & 0.09 & $9.5 \%$ \\
\hline Total & 1.00 & 1.00 & 1.00 & 1.00 & 1.00 & 1.00 & 1.00 & 1.00 & 1.00 & 1.00 & $100 \%$ \\
\hline
\end{tabular}

Source: Research survey

\section{Consistency ratio (CR)}

Finally, it was checked that the values in the pair-wise matrix (table 4) were consistent. This is checked by the Consistency ratio (CR) which is calculated from Consistency Index (CI) and Random Index (RI). For this purpose, firstly, the average ratio was calculated by dividing the sum of respective components' rows by their respective weights found in Table 5. The $\lambda \max$ is the average of all the ratios as sown in Table 6.

Table 6: Calculating $\lambda \max$

\begin{tabular}{|l|l|l|l|l|l|l|l|l|l|l|l|c|}
\hline & KNW & MGT & PLD & HFS & HRC & BPL & ICS & LR & GPS & HSC & SUM & $\begin{array}{c}\text { Ratio }= \\
\text { SUM/Weight }\end{array}$ \\
\hline KNW & 0.15 & 0.16 & 0.18 & 0.17 & 0.12 & 0.13 & 0.18 & 0.13 & 0.18 & 0.17 & 1.56 & 10.24 \\
\hline MGT & 0.15 & 0.16 & 0.16 & 0.16 & 0.13 & 0.13 & 0.17 & 0.10 & 0.24 & 0.21 & 1.61 & 10.28 \\
\hline PLD & 0.07 & 0.08 & 0.08 & 0.07 & 0.07 & 0.09 & 0.12 & 0.10 & 0.06 & 0.07 & 0.80 & 10.20 \\
\hline HFS & 0.20 & 0.22 & 0.24 & 0.22 & 0.22 & 0.20 & 0.24 & 0.24 & 0.27 & 0.25 & 2.28 & 10.23 \\
\hline HRC & 0.05 & 0.05 & 0.05 & 0.04 & 0.04 & 0.03 & 0.03 & 0.03 & 0.05 & 0.04 & 0.42 & 10.21 \\
\hline BPL & 0.05 & 0.05 & 0.04 & 0.05 & 0.06 & 0.04 & 0.04 & 0.04 & 0.04 & 0.03 & 0.44 & 10.14 \\
\hline ICS & 0.05 & 0.05 & 0.04 & 0.05 & 0.07 & 0.06 & 0.05 & 0.10 & 0.04 & 0.05 & 0.55 & 10.15 \\
\hline LR & 0.11 & 0.16 & 0.08 & 0.09 & 0.13 & 0.11 & 0.05 & 0.10 & 0.09 & 0.09 & 1.02 & 10.14 \\
\hline GPS & 0.05 & 0.03 & 0.07 & 0.04 & 0.04 & 0.06 & 0.07 & 0.06 & 0.05 & 0.06 & 0.55 & 10.23 \\
\hline HSC & 0.09 & 0.07 & 0.11 & 0.08 & 0.10 & 0.13 & 0.11 & 0.10 & 0.08 & 0.09 & 0.96 & 10.18 \\
\hline \multicolumn{7}{|c|}{$\lambda$ max Average of the ration } \\
\hline
\end{tabular}

Source: Research survey

The average ratio (10.20) found in Table 6 was used to calculate the consistency index $(\mathrm{CI})$ using the following formula-

Consistency Index $(\mathrm{CI})=(\lambda \max -\mathrm{n}) / \mathrm{n}=(10.20-10) /(10-1)=0.02222$ 
Finally, the value of $\mathrm{CI}$ is used to measure the degree of consistency in the pairwise comparison matrix. The consistency ratio (CR) is the comparison of $\mathrm{CI}$ with the random index (RI) value which was also provided by the Saaty scale. It was found by dividing the CI with random index (RI) as shown in Table 7. For the present study, the RI value is 1.49 for ten HCR components.

Table 7: Calculating consistency ration (CR)



The accepted value of CR is $<0.1$ and $>0$ (Saaty \& Vargas, 1980). Therefore, the calculated CR (0.015) shows a consistent weight of importance for the ten selected components of HCR. Figure 2 presents all the selected ten HCR components arranged according to their measured weightage from the AHP application. It was found that Hygiene and food safety (HFS) had the maximum weightage (22.30\%) followed by Management Responsibility (MGT) as $15.7 \%$, Knowledge on Halal and Toyyib (KNW) as $15.30 \%$, and Legal requirement (LR) in the 4th position with $10 \%$ weightage. The rest of the components had a weightage below $10 \%$ where the least importance was given to Human resources and culture (HRC) as $4.1 \%$, and Branding, packaging, and labelling (BPL) as $4.4 \%$.

Figure 2: The ten selected HCR components and their weightage

\begin{tabular}{llc}
\hline \multicolumn{2}{l}{ HCR Components } & Weightage from AHP \\
\hline 1. & HFS & $22.30 \%$ \\
2. MGT & $15.70 \%$ \\
3. KNW & $15.30 \%$ \\
4. LR & $10.00 \%$ \\
5. HSC & $9.50 \%$ \\
6. PLD & $7.90 \%$ \\
7. ICS & $5.50 \%$ \\
8. GPS & $5.40 \%$ \\
9. BPL & $4.40 \%$ \\
& & \\
10. HRC & $4.10 \%$
\end{tabular}

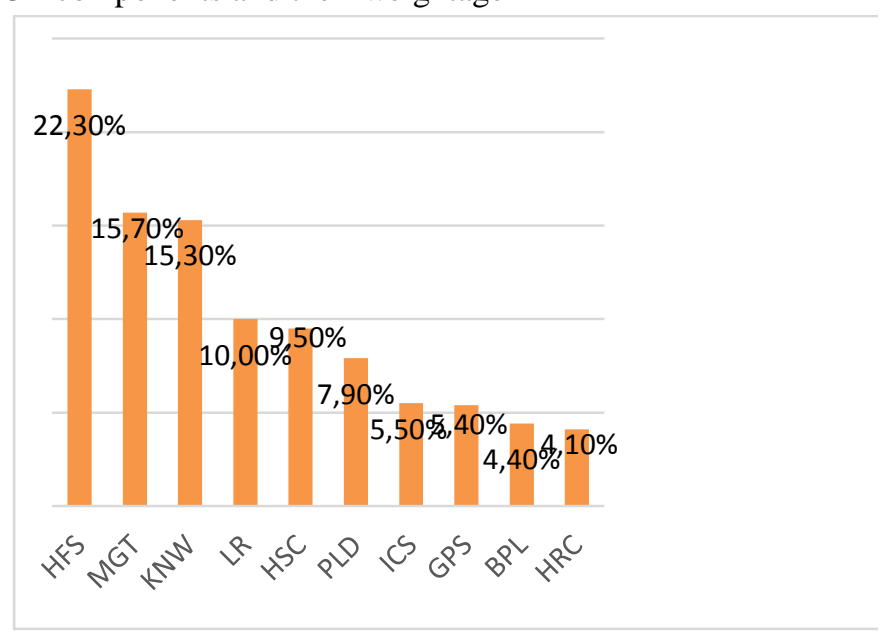

Source: Research Survey

\section{CONCLUSION}

This study identifies ten components of Halal Compliance Rating (HCR) for halalcertified food premises and restaurants in Malaysia. These components have been commonly used in more than one of the different standards (MS1500:2019, MS2610:2015, ISO22000), regulations (Food hygiene regulation 2009), rating system (Crescent Muslim Friendly Hotel 
rating, BeSS certification Malaysia), and previous research works. Hence, these components reflect the best halal compliance practice by the halal-certified food premises and restaurants. To justify the selection of the components, opinions were collected from 20 experts in relevant fields. All of them unanimously agreed that the selected ten components are significantly relevant and important for measuring the level of halal compliance of restaurants and rating them accordingly. The application of the AHP method involving 15 experts revealed that the most important component is Hygiene and food safety (HFS) followed by Management responsibility (MGT), Knowledge on Halal and Toyyib (KNW), Legal requirement (LR), Halal supply chain (HSC), Premise location and design (PLD), Company image and customer satisfaction (ICS), Green practice and sustainability (GPS), Branding, packaging, and labelling (BPL), and the least important is Human resource and culture (HRC). The importance was determined by the calculated weightage of each component from the AHP method which can be used for rating halal compliance of the restaurants in the future. Simultaneously, the study identifies the auditable and measurable areas against each of the ten components by investigating different standards, relevant regulations, rating systems, and existing research works. These items will be useful to prepare an auditing checklist for measuring the level of halal compliance of restaurants and rate them accordingly. The finding of the present study is a potential contribution in developing the halal compliance rating (HCR) tool and its' application in the fields of halal-certified food premises and restaurants in Malaysia.

\section{Limitation}

Regarding halal standards, the present study focuses on Malaysian halal standards only. However, the results and methods can be adapted to other countries as well by integrating their respective halal standards.

Another major limitation of the study is that it aims at food premises and restaurants only in the halal food and beverage industry. To develop a halal compliance rating tool, such investigation of identifying best HCR components can be carried out in other sectors such as halal logistic and supply chain management, halal entrepreneurship management, halal cosmetics and personal care, and other fields in the halal industry.

Finally, the application of the AHP method is limited to finding out the weightage of the selected HCR components through the pairwise comparison and validating them calculating consistency ratio (CR). Further application of AHP is beyond the scope of the study since there is no HCR tool for restaurants and food premises in the halal industry to select the best alternative.

\section{REFERENCES}

Ahmad, A. N. B. (2018). Implementation of Halal Food Management System In Small And Medium Enterprises Food Manufacturers (Issue August). University Putra Malaysia.

Baharuddin, S. A., \& Ismail, R. M. (2018). Halal compliance impact on organizational performance: The role of religiosity. International Journal of Supply Chain Management, 7(5), 455-460.

Department of Standards Malaysia. (2014). MS 2565:2014 Halal Packaging - General 
Guidelines (Patent No. ICS: 55.020). http://www.standardsmalaysia.gov.my

Food Safety and Quality Division, \& Malaysia, M. of H. (2009). FOOD HYGIENE REGULATIONS 2009. https://www.fmm.org.my/images/articles/GS1 Malaysia/Presentation FMM Food Hygiene.pdf

ISO. (2018). ISO22000: Food safety management systems-Requirements for any organization in the food chain. http://www.bizna.ir/upload/emn/1593363136.pdf

JAKIM. (2015). Manual Procedure for Malaysia Halal Certification (Third Revision) 2014. In Manual Procedure for Malaysia Halal Certification (Third Revision) 2014. https://doi.org/10.1017/CBO9781107415324.004

Marzuki, S. Z. S., Hall, C. M., \& Ballantine, P. W. (2012). Restaurant managers' perspectives on halal certification. Journal of Islamic Marketing, 3(1), 47-58. https://doi.org/10.1108/17590831211206581

MS 2610. (2015). Muslim friendly hospitality services - Requirements.

Noordin, N., Md Noor, N. L., Hashim, M., \& Samicho, Z. (2009). Value chain of Halal certification system: A case of the Malaysia Halal Industry. Proceedings of the European and Mediterranean Conference on Information Systems, EMCIS 2009, January 2009.

Rahman, I. N. A., Saleh, R., Rahman, S. A., \& Hashim, D. (2012). A Review on factors of non-compliance of halal standards among restaurant operators in Kuala Lumpur. In International Business Management (Vol. 6, Issue 6, pp. 611-620). https://doi.org/10.3923/ibm.2012.611.620

Razalli, M. R., Abdullah, S., \& Yusoff, R. Z. (2013). The Influence of Human factors in Halal Certification Process on Organizational Performance. World Review of Business Research, 3(3), 157-166.

Romeiss-Stracke, F. (1995). Service-Qualität im Tourismus: Grundsätze und Gebrauchsanweisungen für die touristische Praxis.

Salindal, N. A. (2019). Halal certification compliance and its effects on companies' innovative and market performance. Journal of Islamic Marketing, 10(2), 589-605. https://doi.org/10.1108/JIMA-04-2018-0080

Sorooshian, S., \& Dahan, S. M. (2013). Analysis on factors of non-compliance of Halal standard. Journal of Engineering and Applied Sciences, 8(9), 280-281. https://doi.org/10.3923/jeasci.2013.280.281

STANDARD, M. (2019a). MS 1500:2009 Halal Food - Production, Preparation, Handling and Storage - General Guidelines. Department of Standards Malaysia, 1997.

STANDARD, M. (2019b). MS1480_2019: Food safety according to Hazard Analysis and Critical Point (HACCP) system (second revision) (Patent No. ICS: 67.020). http://www.jsm.gov.my

Tan, B. C., Lau, T. C., Yong, G. F., Khan, N., \& Nguyen, T. P. L. (2019). A qualitative study of green practices adoption for restaurants in Malaysia. Social Responsibility Journal, 15(8), 1087-1099. https://doi.org/10.1108/SRJ-07-2017-0119

Ungku Fatimah, U. Z. A., Boo, H. C., Sambasivan, M., \& Salleh, R. (2011). Foodservice hygiene factors-The consumer perspective. International Journal of Hospitality Management, 30(1), 38-45. https://doi.org/10.1016/j.ijhm.2010.04.001

Yahya, H., Samicho, Z., Firdaus, A., \& Nurul, M. (2016). A Review on Application of 
Halalan-Toyyiban Risk Management Plan ( HTRMP) and Frozen Food Chain during Warehousing Activities for Maintaining Halal, Safety, and Quality. Journal of Applied Enviromental and Biological Sciences, 6(11), 96-102.

Zannierah, S., \& Marzuki, S. (2016). Halal Certification: A Viewpoint From Malaysian Restaurant Managers. Asia-Pacific Journal of Business Review, 1(1), 23-39. https://doi.org/10.20522/APJBR.2016.1.1.23

Zannierah Syed Marzuki, S., Hall, C. M., \& Ballantine, P. W. (2012). Restaurant managers' perspectives on halal certification. Journal of Islamic Marketing, 3(1), 47-58. https://doi.org/10.1108/17590831211206581

Zwillinger, D. (2018). CRC standard mathematical tables and formulas. chapman and hall/CRC. 